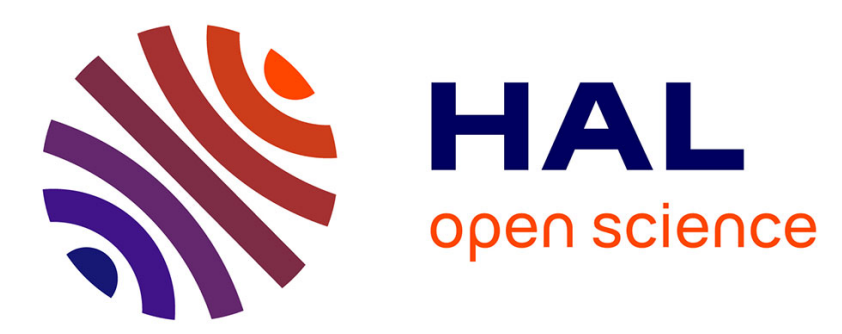

\title{
Kishk - a dried fermented milk / cereal mixture. 4. Microbiological quality
}

\author{
Adnan Y. Tamime, David Mcnulty
}

\section{To cite this version:}

Adnan Y. Tamime, David Mcnulty. Kishk - a dried fermented milk / cereal mixture. 4. Microbiological quality. Le Lait, 1999, 79 (4), pp.449-456. hal-00929664

\section{HAL Id: hal-00929664 https://hal.science/hal-00929664}

Submitted on 1 Jan 1999

HAL is a multi-disciplinary open access archive for the deposit and dissemination of scientific research documents, whether they are published or not. The documents may come from teaching and research institutions in France or abroad, or from public or private research centers.
L'archive ouverte pluridisciplinaire HAL, est destinée au dépôt et à la diffusion de documents scientifiques de niveau recherche, publiés ou non, émanant des établissements d'enseignement et de recherche français ou étrangers, des laboratoires publics ou privés. 


\title{
Original article
}

\section{Kishk - a dried fermented milk/cereal mixture. 4. Microbiological quality}

\author{
Adnan Y. Tamime ${ }^{\mathrm{a} *}$, David McNulty \\ ${ }^{a}$ Food Standards \& Product Technology Department, SAC - Auchincruive, \\ Ayr KA6 5HW, Scotland, United Kingdom \\ ${ }^{\mathrm{b}}$ Biomathematics \& Statistics Scotland, University of Edinburgh, James Clerk Maxwell Building, \\ The King's Building, Edinburgh EH9 3JZ, Scotland, United Kingdom
}

(Received 6 March 1998; accepted 24 November 1998)

\begin{abstract}
The microflora of 25 samples of Kishk were determined. Pathogens such as Staphylococcus aureus, Escherichia coli, Salmonella sp., Listeria sp., Campylobacter sp., Yersinia sp. and Brucella sp. were not recovered from any of the samples at the levels tested. Enterotoxins of staphylococci, bacilli and clostridia also were not detected. Bacillus cereus, aerobic spores, total viable count and contaminants were recovered in appreciable numbers, and some $B$. cereus strains that may produce toxins could be the major bacteriological risk associated with this product. Coliforms, faecal enterococci and Clostridium perfringens were only recovered from samples 7 and 1, respectively. However, yeasts and moulds were recovered intermittently from some of the Kishk samples, and the possible high count of yeast $\left(8.5 \times 10^{5} \mathrm{cfu} \cdot \mathrm{g}^{-1}\right)$ could be attributed to the possible use of 'artisan'-type starter culture containing lactose fermenting yeast. The lactic acid bacteria counts were up to $3.0 \times 10^{3} \mathrm{cfu} \cdot \mathrm{g}^{-1}$ and $1.2 \times 10^{6} \mathrm{cfu} \cdot \mathrm{g}^{-1}$ for lactococci and lactobacilli, respectively. The overall inherent characteristics of Kishk ( 0.4 water activity $\left[\mathrm{A}_{\mathrm{w}}\right], 3.8 \mathrm{pH}$, high in salt and contains a wide range of organic acids) contributes towards the microbiological safety of the product. () Inra/Elsevier, Paris.
\end{abstract}

\section{Kishk / microbial count and toxin / water activity}

Résumé - Le kishk - un mélange lait/céréales fermenté et séché. 4. Qualité microbiologique. La microflore de 25 échantillons de kishk a été déterminée. Les bactéries pathogènes telles que Staphylococcus aureus, Escherichia coli, Salmonella sp., Listeria sp., Campylobacter sp., Yersinia sp. et Brucella sp. n'étaient pas présentes dans les échantillons aux niveaux testés. Les entérotoxines de staphylocoques, de bacilles ou de clostridies n'ont pas non plus été détectées. Des quantités appréciales de Bacillus cereus, spores aérobies, flore totale et contaminants étaient dénombrées ; certaines souches de $B$. cereus qui peuvent produire des toxines constitueraient le principal risque bactériologique associé à ce produit. Des bactéries coliformes, entérocoques fécaux et Clostridium

\footnotetext{
* Correspondence and reprints. a.tamime@au.sac.ac.uk
} 
perfringens ont été trouvés seulement dans les échantillons numéros 1 et 7 . Cependant, des levures et des moisissures étaient retrouvées par intermittence dans quelques échantillons de kishk, et la population élevée de levures $\left(8,5 \times 10^{5} \mathrm{ufc} \cdot \mathrm{g}^{-1}\right)$ pourrait être attribuée à l'utilisation d'un levain « artisanal » contenant des levures fermentant le lactose. Les dénombrements des bactéries lactiques atteignaient $3,0 \times 10^{3} \mathrm{ufc} \cdot \mathrm{g}^{-1} \mathrm{et} 1,2 \times 10^{6} \mathrm{ufc} \cdot \mathrm{g}^{-1}$ respectivement pour les lactocoques et les lactobacilles. Les caractéristiques physico-chimiques du kishk (Aw de 0,$4 ; \mathrm{pH}$ de 3,$8 ;$ forte teneur en sel ; forte variété d'acides organiques) contribuent à assurer la sécurité microbiologique de ce produit. (C) Inra/Elsevier, Paris.

kishk / dénombrement microbien / toxine microbienne / activité de l'eau

\section{INTRODUCTION}

The traditional method for the manufacture of Kishk is very basic [24], and the microbiological quality of the product is mainly governed by factors such as: 1) the method used to ferment the milk; 2) the hygienic conditions practised during the manufacturing stages including whether or not the milk was heat treated (e.g. boiled) before the fermentation stage; and 3) the drying stage in the open air in the sun. Three possible types of lactic fermentation may be distinguished during the manufacture of Kishk: first, unknown composition of the starter culture where the indigenous microflora is used to ferment the unheated milk; second, 'artisan' starter culture is normally used frequently by seeding the milk with yoghurt or another type of fermented milk from the previous day's batch, and hence, the starter composition may be variable; and third, selected lactic starter cultures obtained from commercial sources of known composition.

It is evident that acidification of milk can extend the shelf-life of the manufactured products, and limited data are available on the microbiological quality of Kishk. Nevertheless, the low moisture content $(<10 \%)$, acidic nature of the product $(\sim 3.8 \mathrm{pH})$ and the addition of salt during manufacture $\left(\sim 2.8 \mathrm{~g} \cdot 100 \mathrm{~g}^{-1} \mathrm{NaCl}\right.$ in the dried product) may suggest the microbiological safety of Kishk [25].
Faecal enterococci count at a level of $3.4 \times 10^{2}$ colony forming units $(\mathrm{cfu}) \cdot \mathrm{g}^{-1}$ was reported by Atia and Khattab [2] in only one of eight Egyptian Kishk samples tested. However, the groups of undesirable microorganisms, which were found in different commercial samples of Kishk, were mainly spore-formers (i.e. Bacillus spp.), yeasts and moulds [24]. In Iran, the death of two people, who had clinical symptoms of botulism food poisoning, was associated with the consumption of Kishk, and Haydarynia [9] reported the growth, survival and production of toxin of Clostridium botulinum in laboratory-made Kishk.

In previous studies the chemical and nutritional properties of Kishk were detailed [25-27]. The objective of this study was to investigate the microbiological evaluation of 25 different samples of Lebanese Kishk.

\section{MATERIALS AND METHODS}

\subsection{Kishk samples}

Twenty-five samples of commercial Kishk $(\sim 1 \mathrm{~kg}$ each) were obtained from different retail outlets in Lebanon [25].

\subsection{Analytical methods}

\subsubsection{Water activity $\left(A_{\psi}\right)$ and $p H$}

The water activity in the Kishk samples was determined according to the method described 
by O'Brian [21]. All measurements were made with an $\mathrm{A}_{w}$ Portimeter Dewpoint Meter DP 383R (Portimeter Ltd., Marlow, UK) placed in a warm room at a nominal temperature of $25^{\circ} \mathrm{C}$. As the Kishk products had low $\mathrm{A}_{w}$, equilibration of the chamber for $24 \mathrm{~h}$ was employed. A standard solution of $\mathrm{NaCl}$ was checked weekly as a control.

The $\mathrm{pH}$ in the Kishk samples was measured according to the method described by Tamime et al. [25].

\subsubsection{Microbiological analysis}

The Kishk samples were transported to Scotland by air at ambient temperature and stored at $\sim 5^{\circ} \mathrm{C}$ on arrival for around 6 months. A wide range of microbiological tests including toxin determinations were carried out, and table I summarises such analysis, including the methods used. The preparation of each sample and dilutions for microbiological examination was carried out according to the method described by IDF [20]. Each Kishk sample ( $10 \mathrm{~g})$ was homogenised in $90 \mathrm{~mL}$ of sterile $2 \%$ sodium citrate solution at $\sim 7{ }^{\circ} \mathrm{C}$ for $15 \mathrm{~s}$ in a Colworth Stomacher 400 model BA 6021 (A.J. Seward Medical, London, UK). Serial dilutions were made in $/ 1 / 4$ strength sterile Ringer's solution and plated in duplicate on specific agar, and the average of the determinations was expressed as $\mathrm{cfu} \cdot \mathrm{g}^{-1}$.

\subsection{Statistical analysis}

The data were analysed using graphical exploratory data analysis techniques available in Minitab 10.2 (copyright Minitab, Inc., 1994).

\section{RESULTS AND DISCUSSION}

\subsection{Chemical and nutritional composition of Kishk samples}

The average chemical composition (protein, fat, carbohydrates, ash, organic acids and fatty acids) and micronutrients (mineral, selenium, amino acids and vitamins) including $\beta$-glucan, fibre, phytic acids contents and profiling of the proteins of 25 samples of Lebanese Kishk have been reported by Tamime et al. [25-27].
Table I. Methods used for the microbiological analysis of Kishk ${ }^{\mathrm{a}}$.

Tableau I. Méthodes utilisées pour l'analyse microbiologique du kishk ${ }^{\mathrm{a}}$.

Microorganism/

Reference

test method

Total viable count $t^{b}$

Total microbial contaminants $\mathrm{s}^{\mathrm{c}}$

Psychrotrophic count

Coliforms (MPN) ${ }^{\mathrm{d}}$

Staphylococcus aureus

Lactic acid bacteria ${ }^{e}$

Yeasts and moulds ${ }^{f}$

Listeria monocytogenes

Salmonella spp.

Escherichia coli (MPN)

Bacillus cereus

Clostridium perfringens

Enterococcus faecalis (MPN)

Aeromonas hydrophila

Pseudomonas spp.

Campylobacter spp.

Clostridia (MPN)

Aerobic spore former count

Yersinia spp.

Brucella spp.

a Most of the tests used in this study were performed on spiral plate technique as opposed to spread or pour plate; ${ }^{b}$ total count of bacteria, yeasts and moulds; ${ }^{c}$ non-lactic acid bacteria, yeasts and moulds; ${ }^{\mathrm{d}} \mathrm{MPN}$ : most probable number; ${ }^{\mathrm{e}}$ thermophilic lactic acid bacteria mainly to enumerate yoghurt starter cultures; ${ }^{f}$ oxytetracycline was replaced by chloramphenicol; $\mathrm{g}$ test methods were described by the Oxoid Manual including the enterotoxin detection of $S$. aureus, $B$. cereus and $C$. perfringens.

a La plupart des tests dans cette étude ont été réalisés par ensemencement spiral plutôt que par étalement ou ensemencement dans la masse. ${ }^{b}$ Dénombrement total des bactéries, levures et moisissures. ${ }^{\mathrm{c}}$ Bactéries nonlactiques, levures et moisissures. ${ }^{\mathrm{d}} \mathrm{MPN}$ - nombre le plus probable. ${ }^{\mathrm{e}}$ Bactéries lactiques thermophiles (principalement pour dénombrer les levains du yaourt). ${ }^{\mathrm{f}}$ L'oxytetracycline a été remplacée par du chloramphenicol, ${ }^{g}$ Les méthodes sont décrites dans le manuel Oxoid avec la détection des enterotoxines de $S$. aureus. $B$. cereus et $C$. perfringens. 


\subsection{Water activity $\left(\mathrm{A}_{\mathrm{w}}\right)$ and $\mathrm{pH}$}

The residual microbial activity in food products is dependent on a multitude of factors such as availability of nutrients, storage conditions, acidity, salt level and/or water activity. The $\mathrm{A}_{\mathrm{w}}$ readings of 25 samples of the Kishk ranged between 0.34 and 0.43 (table II), which are proving to be rather low to support the growth of microorganisms that not even the most xerophilic mould could grow.

The salt, $\mathrm{pH}$ and certain organic acids contents of these Kishk samples have been also included in table II for comparative purposes where such data may provide the relevant information that may influence the survival of certain microorganisms in the dried product. For example, the $\mathrm{p} K_{\mathrm{a}}$ of lactic < acetic < propionic acids [5], and the undissociated acid is more active as an antimicrobial to inhibit the growth of pathogens and other undesirable microorganisms [1].

\subsection{Microbiological quality}

The microorganisms that have been detected in the Kishk samples are shown in table III. The total viable count (TVC) in 20 samples of Kishk ranged between $3.1 \times 10^{2}$ and $1.1 \times 10^{6} \mathrm{cfu} \cdot \mathrm{g}^{-1}$. No TVC was recovered from Kishk samples 21, 23 and 24 , suggesting that the fermented milk/cereal mixture was subjected to heat treatment before drying; however, counts for samples 4 and 5 could not be carried out due to the presence of spreading colonies, probably Bacillus sp. Similar pattern of counts were observed when the total contaminant count (i.e. $2.8 \times 10^{2}$ to $1.3 \times 10^{6} \mathrm{cfu} \cdot \mathrm{g}^{-1}$ ) was performed (table III), including Kishk samples 4, 5, 21, 23 and 24 (for sample identification, refer to [25]). Similar total counts of commercial and laboratory-made Kishk have been reported elsewhere [24]. However, the low microbial contaminants count ranged between $<10$ and $4.7 \times 10^{2} \mathrm{cfu} \cdot \mathrm{g}^{-1}$ for Kishk samples 1, 2, 7, 9, 10, 21, 23 and 24 , whilst highest counts $\left(1.3 \times 10^{5}\right.$ to $1.3 \times 10^{6}$ ) were recovered from samples 3 , $12,13,16$ and 17 . The high microbial contamination in these Kishk samples reflect the poor sanitary conditions during the manufacturing stages or post-production contamination, and interestingly four of these products were made by non-dairy organisations.

The presence of coliforms were only detected in Kishk samples 3 and 13 which yielded 24 and 43 MPN (most probable num-

Table II. Measurements of available water, $\mathrm{pH}$, salt and certain organic acid contents of different samples of Lebanese Kishk.

Tableau II. Détermination de l'eau disponible, du pH, du sel et de certains acides organiques dans différents échantillons de kishk libanais.

\begin{tabular}{lccc}
\hline Component & Minimum & Maximum & Mean \\
\hline Water activity $\left(\mathrm{A}_{\mathrm{w}}\right)$ & 0.34 & 0.43 & 0.40 \\
Salt $\left(\mathrm{g} \cdot 100 \mathrm{~g}^{-1}\right)^{\mathrm{a}}$ & 1.0 & 4.5 & 2.9 \\
$\mathrm{pH}^{\mathrm{a}}$ & 3.63 & 4.12 & 3.77 \\
& & & \\
Organic acids $\left(\mathrm{mg} \cdot \mathrm{g}^{-1}\right)^{\mathrm{a}}$ & 18.75 & 43.87 & 32.47 \\
$\quad$ Lactic & 0.40 & 0.86 & 0.59 \\
Acetic & 0.92 & 7.45 & 3.55 \\
$\quad$ Propionic & & \\
\hline
\end{tabular}

\footnotetext{
a Data compiled from [25].

a Données issues de Tamime et al. [25].
} 
Table III. Microbiological quality of different Kishk samples.

Tableau III. Qualité microbiologique de différents échantillons de kishk.

\begin{tabular}{|c|c|c|c|c|c|c|c|c|}
\hline \multirow[b]{2}{*}{$\begin{array}{l}\text { Sample } \\
\text { number }^{\mathrm{a}}\end{array}$} & \multicolumn{6}{|c|}{ Colony forming units $(\mathrm{cfu}) \cdot \mathrm{g}^{-1}$} & \multicolumn{2}{|c|}{ Most probable number } \\
\hline & $\begin{array}{l}\text { Total } \\
\text { count }\end{array}$ & Contaminants & $\begin{array}{l}\text { Aerobic } \\
\text { spores }\end{array}$ & B. cereus & Yeasts & Moulds & Coliforms & $\begin{array}{c}\text { Faecal } \\
\text { enterococci }\end{array}$ \\
\hline 1 & $4.2 \times 10^{4}$ & $4.7 \times 10^{2}$ & $<10$ & $<10$ & $<10$ & $<10$ & $<0.3$ & $<0.3$ \\
\hline 2 & $3.7 \times 10^{4}$ & $2.8 \times 10^{2}$ & $<10$ & $<10$ & $8.0 \times 10^{2}$ & $6.0 \times 10^{2}$ & $<0.3$ & $<0.3$ \\
\hline 3 & $1.0 \times 10^{6}$ & $1.0 \times 10^{6}$ & $5.0 \times 10^{3}$ & $6.0 \times 10^{2}$ & $8.5 \times 10^{5}$ & $<10$ & 24 & 240 \\
\hline 4 & $\mathrm{sc}^{\mathrm{b}}$ & $\mathrm{sc}$ & $1.4 \times 10^{6}$ & $1.3 \times 10^{5}$ & $<10$ & $<10$ & $<0.3$ & $<0.3$ \\
\hline 5 & sc & $\mathrm{sc}$ & $1.4 \times 10^{6}$ & $7.8 \times 10^{4}$ & $<10$ & $<10$ & $<0.3$ & $<0.3$ \\
\hline 6 & $4.2 \times 10^{4}$ & $2.8 \times 10^{4}$ & $3.4 \times 10^{3}$ & $1.5 \times 10^{3}$ & $3.0 \times 10^{3}$ & $<10$ & $<0.3$ & 240 \\
\hline 7 & $6.0 \times 10^{2}$ & $3.7 \times 10^{2}$ & $<10$ & $<10$ & $<10$ & $<10$ & $<0.3$ & $<0.3$ \\
\hline 8 & $1.8 \times 10^{4}$ & $8.0 \times 10^{4}$ & $<10$ & $<10$ & $7.0 \times 10^{3}$ & $<10$ & $<0.3$ & 9 \\
\hline 9 & $3.0 \times 10^{2}$ & $2.8 \times 10^{2}$ & $<10$ & $<10$ & $1.0 \times 10^{3}$ & $1.6 \times 10^{2}$ & $<0.3$ & $<0.3$ \\
\hline 10 & $3.0 \times 10^{2}$ & $3.4 \times 10^{2}$ & $1.4 \times 10^{3}$ & $<10$ & $<10$ & $<10$ & $<0.3$ & $<0.3$ \\
\hline 11 & $9.5 \times 10^{3}$ & $4.6 \times 10^{3}$ & $6.1 \times 10^{2}$ & $<10$ & $4.0 \times 10^{3}$ & $1.0 \times 10^{2}$ & $<0.3$ & 24 \\
\hline 12 & $1.1 \times 10^{6}$ & $1.0 \times 10^{6}$ & $9.0 \times 10^{5}$ & $<10$ & $<10$ & $<10$ & $<0.3$ & $<0.3$ \\
\hline 13 & $9.2 \times 10^{5}$ & $1.2 \times 10^{6}$ & $1.3 \times 10^{6}$ & $2.4 \times 10^{4}$ & $2.2 \times 10^{3}$ & $<10$ & 43 & 93 \\
\hline 14 & $1.4 \times 10^{3}$ & $2.2 \times 10^{3}$ & $2.5 \times 10^{3}$ & $<10$ & $<10$ & $<10$ & $<0.3$ & $<0.3$ \\
\hline 15 & $1.1 \times 10^{6}$ & $9.0 \times 10^{5}$ & $4.1 \times 10^{5}$ & $<10$ & $<10$ & $<10$ & $<0.3$ & $<0.3$ \\
\hline 16 & $9.4 \times 10^{4}$ & $1.3 \times 10^{5}$ & $5.4 \times 10^{4}$ & $<10$ & $<10$ & $<10$ & $<0.3$ & $<0.3$ \\
\hline 17 & $1.3 \times 10^{4}$ & $1.3 \times 10^{6}$ & $1.2 \times 10^{6}$ & $5.6 \times 10^{4}$ & $<10$ & $<10$ & $<0.3$ & $<0.3$ \\
\hline 18 & $3.2 \times 10^{3}$ & $2.2 \times 10^{3}$ & $6.4 \times 10^{3}$ & $<10$ & $<10$ & $<10$ & $<0.3$ & $<0.3$ \\
\hline 19 & $3.7 \times 10^{3}$ & $3.0 \times 10^{3}$ & $3.2 \times 10^{3}$ & $<10$ & $<10$ & $<10$ & $<0.3$ & $<0.3$ \\
\hline 20 & $1.7 \times 10^{3}$ & $1.6 \times 10^{3}$ & $1.8 \times 10^{3}$ & $<10$ & $<10$ & $<10$ & $<0.3$ & 240 \\
\hline 21 & $<10$ & $<10$ & $<10$ & $<10$ & $<10$ & $<10$ & $<0.3$ & $<0.3$ \\
\hline 22 & $1.1 \times 10^{4}$ & $9.0 \times 10^{3}$ & $9.8 \times 10^{3}$ & $2.4 \times 10^{3}$ & $<10$ & $<10$ & $<0.3$ & 43 \\
\hline 23 & $<10$ & $<10$ & $<10$ & $<10$ & $<10$ & $<10$ & $<0.3$ & $<0.3$ \\
\hline 24 & $<10$ & $<10$ & $<10$ & $<10$ & $<10$ & $<10$ & $<0.3$ & $<0.3$ \\
\hline 25 & $4.2 \times 10^{3}$ & $5.4 \times 10^{3}$ & $4.0 \times 10^{3}$ & $<10$ & $<10$ & $<10$ & $<0.3$ & $<0.3$ \\
\hline
\end{tabular}

${ }^{\mathrm{a}}$ For sample identification, refer to [25]. ${ }^{\mathrm{b}}$ spreading colonies, plates could not be counted.

${ }^{a}$ Voir Tamime et al. [25] pour l'identification des échantillons. ${ }^{\mathrm{b}}$ Colonies filantes, les boîtes ne pouvaient pas être comptées. 
ber), respectively. Faecal enterococci were only recovered from Kishk samples 3, 6, 8, $11,13,20$ and 22 at low levels (table III). It may be significant to point out that samples 3 and 20 had relatively high $\mathrm{pH}$ (4.1) when compared with the rest of the Kishk samples (i.e. $\mathrm{pH} \leq 3.8$ ), and both samples had coliforms and faecal enterococci. The low counts of these indicator organisms in Kishk could be attributed to the die-off as a result of low $\mathrm{A}_{\mathrm{w}}$ and low $\mathrm{pH}$ of the product (table II). In addition, the psychrotrophic count of $1.0 \times 10^{3} \mathrm{cfu} \cdot \mathrm{g}^{-1}$ was only obtained in Kishk sample 3 .

Aerobic spores were present in 17 samples of Kishk in numbers ranging from $6.1 \times 10^{2}$ to $1.43 \times 10^{6} \mathrm{cfu} \cdot \mathrm{g}^{-1}$ (table $/ I I$ ). However, seven of the Kishk samples yielded $B$. cereus at levels ranging between $6.0 \times 10^{2}$ and $1.34 \times 10^{5} \mathrm{cfu} \cdot \mathrm{g}^{-1}$. Similar counts have been reported by Atia and Khattab [2] on Egyptian Kishk. The presence of B. cereus in Kishk is not surprising as this microorganism is one of the common contaminants of milk, and is most likely to be present in the parboiled cracked cereal (Burghol) (Khaskheli and Tamime, unpublished data). B. cereus produce spores which are likely to survive in the Kishk. Some strains of $B$. cereus produce toxins which may cause food poisoning, and it could be considered the major bacteriological risk associated with this product; however, $B$. cereus toxin was not detected in any of the Kishk samples. Furthermore, $C$. perfringens was only recovered from Kishk sample 3 at a very low level $(3.0 \times$ $10^{-1} \mathrm{cfu} \cdot \mathrm{g}^{-1}$ ) which may not be a significant count bacteriologically, and no toxin was detected. The MPN of clostridia were 2.3 and 0.92 which were recovered from Kishk samples 3 and 7 , respectively.

The yeasts and mould counts were recovered intermittently from the samples (table III). Moulds were only detected in Kishk samples 2,9 and 11, and the counts were $6.0 \times 10^{2}, 1.6 \times 10^{2}$ and $1.0 \times 10^{2} \mathrm{cfu} \cdot \mathrm{g}^{-1}$, respectively. The yeasts counts ranged between $8.0 \times 10^{2}$ and $8.54 \times 10^{5} \mathrm{cfu} \cdot \mathrm{g}^{2}$, and were recovered only in samples 2, 3, 6, 8,11 and 13. Slightly lower yeasts and moulds counts have been found in Kishk [24], but the high yeast count could be attributed to the 'artisan' starter culture used which may contain lactose fermenting yeast [3].

With respect to lactococci and lactobacilli counts, spreading colonies appeared in the majority of the agar plates which made the LAB counts in the Kishk very difficult, and hence, the efficacy of the final count may be inaccurate. However, some of the counts ranged between $1.4 \times 10^{2}$ and $3.4 \times 10^{3} \mathrm{cfu} \cdot \mathrm{g}^{-1}$ for Lactococcus sp. and $1.3 \times 10^{2}$ and $1.2 \times 10^{6} \mathrm{cfu} \cdot \mathrm{g}^{-1}$ for Lactobacillus sp. (counts are now shown).

In this survey, Staphylococcus aureus, Escherichia coli, Aeromonas sp., Pseudomonas sp. psychrotrophic count and Brucella abortus were not recovered from any of the Kishk samples at the level tested (i.e. $10^{-1}$ dilution), and Salmonella sp., Listeria sp., Campylobacter sp. and Yersinia sp. were not recovered in $25 \mathrm{~g}$ of the product.

Figure 1 illustrates a matrix plot for TVC, contaminants count and aerobic spores count. When the labelled outlier Kishk samples were omitted from the calculations, all three variable microbiological counts were strongly correlated. The outlier samples did not have anything in common with each other nor were they distinguished from the other samples except when plotted. There were insufficient colony counts for the enumeration of the remaining microorganisms shown in table III to examine these counts in detail. However, when the microbial counts in figure $l$ were related to variables (i.e. source, type of milk or packaging system; see table I in [25]), there did not appear to be any correlation between them.

\section{CONCLUSION}

Given the conditions during the manufacture of Kishk, the overall indicator 
Figure 1. Scatter plot of total viable count, contaminants count and aerobic spores count of Kishk samples.

Figure 1. Représentation de la dispersion des dénombrements en flore totale, contaminants et spores aérobies dans les échantillons de kishk.

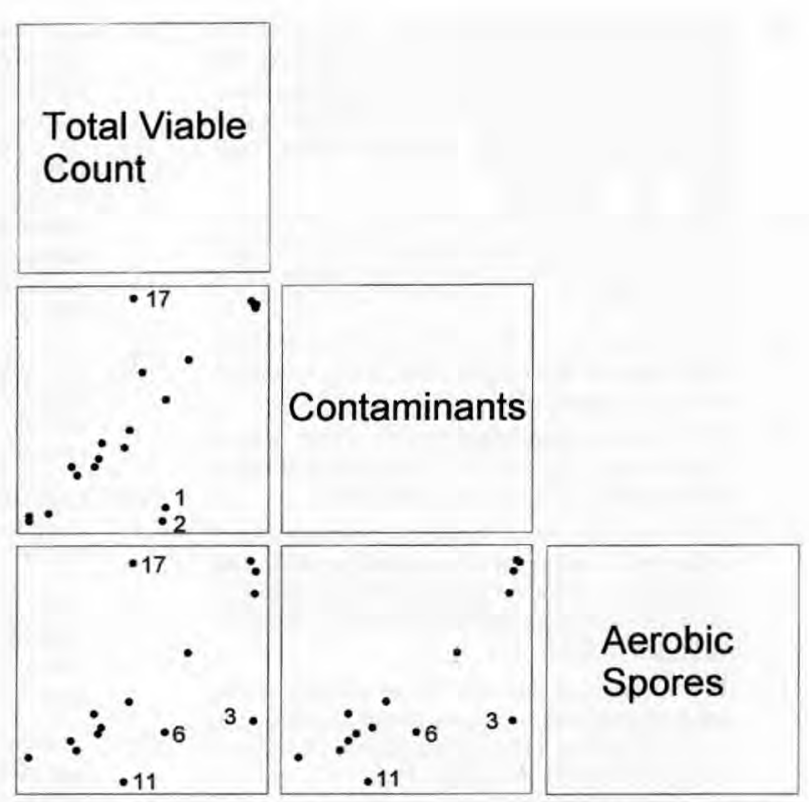

microorganisms are only present in low numbers in the product and in microbiological terms, are relatively safe and stable. This could be attributed to a multitude of factors such as: low water activity, high salt and the presence of a wide range of organic acids and low $\mathrm{pH}$. However, in present-day terminology these would be considered as 'hurdles', and it is interesting to observe how a traditional method of manufacture effectively mimics present-day food safety principles at least as far as preventing the growth of spores and B. cereus toxin. In addition, the intended use of Kishk is rehydrating with water followed directly by cooking to prevent the growth of undesirable microorganisms. There are indications in these microbiological results that the product quality is variable, with some samples showing noticeably more contamination than others. This is probably a reflection of the standards of hygiene applied during production and the quality of raw materials used, mainly the Burghol, and it indicates that with improved hygiene, the microbiological quality of the Kishk could be improved.

\section{ACKNOWLEDGEMENTS}

The authors thank Mr. S. Crawford and Ms. L. Drysdale for skilled technical assistance. SAC and BioSS receive financial support from the Scottish Office of Agriculture, Environment and Fisheries Department (SOAEFD).

\section{REFERENCES}

[1] Adams M.R., Hall C.J., Growth inhibition of food-borne pathogens by lactic acetic acids and their mixtures, Int. J. Food Sci. Technol. 23 (1988) 287-292.

[2] Atia I.A., Khattab A.A., Microbiological and chemical studies on Kishk, Alexandria Sci. Exchange 6 (1985) 63-71.

[3] Baroudi A.A.G., Collins E.B., Microorganisms and characteristics of Laban, J. Dairy Sci. 59 (1976) 200-202.

[4] Bridson E.Y., The Oxoid Manual, 6th edn., Unipath Ltd., Basingstoke, 1990, pp. 2: 32-33, $39-41,56-57,70-71,174-179$ and $10: 1$.

[5] Doores S., Organic acids, in: Davidson P.M., Branen A.L. (Eds.), Antimicrobials in Foods, 2nd edn., Marcel Dekker, New York, 1993, pp. 95-136.

[6] Farrell I.D., The development of new selective medium for the isolation of Brucella abortus from contaminated sources, Res. Vet. Sci. 16 (1974) 280-286. 
[7] Freame B., Fitzpatrick B.W.F., The use of differential reinforced clostridial medium for the isolation and enumeration of clostridia from food, in: Shapton D.A., Board R.G. (Eds.), Isolation of Anaerobes-5, Academic Press, London, 1971, pp. 49-55.

[8] Harrigan W.R., McCance M.E., Laboratory Methods in Food and Dairy Microbiology, revised edition, Academic Press, London, 1976 , pp. 176-177.

[9] Haydarynia A., The survival of Clostridium botulisium in Kushk, 23rd Int. Dairy Congress Brief Commun., Vol. 1, 1990, p. 105.

[10] IDF, Milk and milk products - Detection of Salmonella, Standard 93A, International Dairy Federation, Brussels, Belgium, 1985.

[11] IDF, Milk and milk products. Enumeration of coliforms - colony count technique and most probable number technique at $30^{\circ} \mathrm{C}$, Standard 73A, International Dairy Federation, Brussels, Belgium, 1985.

[12] IDF, Yogurt. Enumeration of characteristic microorganisms - colony count technique at $37^{\circ} \mathrm{C}$, Standard $117 \mathrm{~A}$, International Dairy Federation, Brussels, Belgium, 1988.

[13] IDF, Milk and milk products. Detection of Listeria monocytogenes, Standard 143, International Dairy Federation, Brussels, Belgium, 1990.

[14] IDF, Milk and milk-based products. Enumeration of Staphylococcus aureus - colony count technique at $37^{\circ} \mathrm{C}$, Standard 145 , International Dairy Federation, Brussels, Belgium, 1990.

[15] IDF, Milk and milk products. Enumeration of yeasts and moulds - colony count technique at $25^{\circ} \mathrm{C}$, Standard 94B, International Dairy Federation, Brussels, Belgium, 1990.

[16] IDF, Butter, fermented milks and fresh cheese. Enumeration of contaminating micro-organisms - colony count technique at $30^{\circ} \mathrm{C}$, Standard 153, International Dairy Federation, Brussels, Belgium, 1991.

[17] IDF, Milk and milk products. Enumeration of micro-organisms - colony count technique at $30^{\circ} \mathrm{C}$, Standard 100B, International Dairy Federation, Brussels, Belgium, 1991.
[18] IDF, Milk. Enumeration of psychrotrophic micro-organisms - colony count technique at $6.5^{\circ} \mathrm{C}$, Standard $101 \mathrm{~A}$, International Dairy Federation, Brussels, Belgium, 1991.

[19] IDF, Yogurt. Identification of characteristic micro-organisms (Lactobacillus delbrueckii subsp, bulgaricus and Streptococcus salivarius subsp, thermophilus), Standard 146, International Dairy Federation, Brussels, Belgium, 1991.

[20] IDF, Milk and milk products - Preparation of samples and dilutions for microbiological examination, Standard 122B, International Dairy Federation, Brussels, Belgium, 1992.

[21] O'Brian F.E.M., The control of humidity by saturated salt solutions, J. Sci. Instrum. 25 (1948) 73-76.

[22] Schiemann D.A., Developments of a two-step enrichment procedure for recovery of Yersinia enterocolitica from food, Appl. Environ. Microbiol. 43 (1982) 14-27.

[23] Schiemann D.A., Comparison of enrichment and plating media for recovery of virulent strains of Yersinia enterocolitica from inoculated beef stew, J. Food Protect. 46 (1983) 975-964.

[24] Tamime A.Y., O'Connor T.P., Kishk - a dried fermented milk/cereal mixture, Int. Dairy J. 5 (1995) 109-1280.

[25] Tamime A.Y., Barclay M.N.I., Amarowicz A., McNulty D., Kishk - a dried fermented milk/cereal mixture. 1. Composition of gross components, carbohydrates, organic acids and fatty acids, Lait 79 (1999) 317-330.

[26] Tamime A.Y., Barclay M.N.I., Law A.J.R., Leaver G., Anifantakis E.M., O'Connor T.P., Krause I., Kishk - a dried fermented milk/cereal mixture. 2. Assessment of a variety of protein analytical techniques for determining adulteration and proteolysis, Lait 79 (1999) 331-339.

[27] Tamime A.Y., Barclay M.N.I., McNulty D., O'Conner T.P., Kishk - a dried fermented milk/cereal mixture. 3. Nutritional composition, Lait 79 (1999) 435-448. 